\title{
3. Small Pacific states and media freedom: A Kiribati case study
}

\section{ABSIRACI}

For more than 50 years, the governments of Kiribati have manipulated the affairs of the Broadcasting and Publications Authority (BPA). The authority runs a radio station and newspaper reaching the majority of the population of Kiribati. The interference is simply a warning to those working for the authority that they do not have freedom to inform the public. In practice, the political opposition would oppose this interference, describing it as draconian and demanding more media freedom. But when the opposition came to power, it would also restrict the work of journalists. Thus reporters have often been caught in the crossfire between the politicians and are fearful of their future. Some journalists have been accused of being anti-government or sanctioning stories that embarrass the political leaders. This commentary explains - from the firsthand experience of this journalist - why in the digital era small Pacific nations such as Kiribati face a more fundamental issue: protecting the public's right to know.

\section{TABERANNANG KORAUABA}

Publisher-editor, Tematairiki

\section{Introduction}

7 IRIBATI, formerly the Gilbert Islands, is a Micronesian nation comprising 33 atolls in three main groups - the Gilbert Islands,

1 Phoenix Islands and Line Islands. The atolls are spread over a vast section of the Pacific Ocean, stretching nearly $4000 \mathrm{~km}$ from east to west and more than $2000 \mathrm{~km}$ from north to south. The official language of the republic, a former British colony, is English and many i-Kiribati people speak this in addition to the vernacular language, Kiribati.

The Broadcasting and Publications Authority (BPA) is the governmentowned station which operates Radio Kiribati and the weekly newspaper, Te Uekera. The authority was set up in 1954 by the British during the colonial 
period. The BPA dominates Kiribati's media scene, reaching the majority of the estimated population of 100,000. During 2006, executives of the authority have sought to expand their broadcasting services to the islands in the east. If that is successful, then the state radio is very likely to cover all the atolls of the nation by the year 2010. The public is increasingly relying on this station for information. Whatever information is broadcast on Radio Kiribati is presumed to be the 'truth' and cannot be questioned. Perhaps this is why it is extremely powerful in many respects when compared with other news media outlets currently operating in the country. This has prompted governments to make up their own claims, accusing the reporters of being 'anti-government'. Understandably, they might call the BPA a nuisance when it continues to run stories that cause political embarrassment. Consequently, the reporters tend to pull back because they do not want to lose their job and choose to do 'light' stories instead. Their job - which is to inform the public - has been hampered by interference by governments, and the publicís right to know is at risk. When challenged about its stance over BPA, the government says, the public broadcaster 'needs to work within the limits of the BPA law' (Pacnews, 1 August 2005), implying that the government has a mandate to 'censor you'.

\section{Background}

\section{State-run media}

The BPA was established after the radio stations in British colonies in the Pacific were successfully set up. Such stations in the region included the Fiji Broadcasting Corporation Ltd, which runs Radio Fiji; and the Solomon Islands Broadcasting Services. The aim for establishing public broadcasters was to ensure British control. The authority, for instance, was established with that objective. The programme contents of Radio Kiribati at that time were provided by the Office of the Resident Commissioner in Bairiki, appointed by the British government to oversee the daily administration of the colony. In addition, the authority was regulated by the Broadcasting andPublications Authority Ordinance 1979, passed by the British in the year of independence. That law is still being applied-with some minor changes while the sections giving absolute poweríto the political leaders remain intact.

Other media outlets:

In Kiribati, private media includes the Kiribati Newstar newspaper (weekly circulation 2000 copies) and Newair FM89, owned by former 
President Ieremia Tabai and three others; Te Mauri, a weekly newspaper published by the Kiribati Protestant Church in the Kiribati language; and a television service introduced in 2004 by Telecom Kiribati Ltd (TKL). The newspapers are published every week focusing mainly on local issues. They cover some international and regional news, although this is often done through 'copy and paste'. The TV just broadcasts minor programmes and for limited hours. I make special reference to these news media outlets because the combined audiences and readership are far less than those of Radio Kiribati listeners.

\section{Independence aftermath}

Kiribati achieved independence in 1979. It was considered by many to be freedom-to-do-whatever-you-want era. Our people have been confused over independence, which is simply referred to as the right to govern ourselves. They thought that the government's properties belonged to them too. Later, Tabai found that this mentality had not helped the country to move forward. Again, I refer to these issues because after independence the political leaders also shared that belief. This was demonstrated when they treated BPA as their own personal property. The BPA remained in place when the British granted the country independence and finally left. But that moment was only the beginning of its colonial history. Kiribati's neo-colonial masters were just being trained and were about to take over. For example, Ieremia Tabai was Kiribati's first President, and he was the youngest man to become President. He grew up when the British ruled the country. Although not much is known about his relationship with BPA, there were reports that he had interfered in the work of the radio station. His government wanted to sack former Radio Kiribati news editor Batiri Bataua, now editor of Te Mauri newspaper, for his controversial story about the government's failed promise to the people of Bonriki over increase of land lease and to not to relocate the villagers - mostlytheindigenousTarawanstoanotherplace(B.Bataua,personal communication, September 2002) and in a film produced by Nei Taberanikai Video Unit in 2003 after the fall of Teburoro's government entitled Koaua aika a riai $n$ ataaki (Truth that should be known). Secondly there were revelations, often made in Parliament (Maneaba), that Tabai shut down the station when the union BKATM Boutokaan Karikirakean Aroia Taani mwakuri (Improving the welfare of the workers) tried to use it to convey a message to their colleagues during a national union strike in 1980. Instead, 
he used the station to muster support from the public who in turn offered to fight the union workers. One union member was shot in the leg.

The President's deputy, Teatao Teannaki, who took over when Ieremia finished his term in 1991, seemed to be disappointed about the stationís coverage of his dealings. Consequently, the president removed a section of the $B P A$ Ordinance granting it exclusive right to do what it thinks important for the public. Both presidents appear to have overlooked the outdated $B P A$ Ordinance, especially Section 10 giving absolute power to the Minister of Communication. They did not change it. Instead, the presidents removed sections of the law, effectively crippling the station's independence.

In 1994, Teburoro Tito was elected President. One of his key campaign promises was to uphold 'the freedom of BPA'. He repeatedly promised this when he was in opposition during the Tabai and Teannaki administrations. However, while in power Teburoro did the opposite thing. He stopped BPA from broadcasting a programme, Kaoti am iango (Present your views), aired over Radio Kiribati every week. His reason was that the radio was allegedly used by the opposition and its supporters. Secondly, Teburoro ordered the BPA directors to edit the contents of the newspaper and radio stories. If in doubt, the directors or manager of the station would fax the copy of the story to the Minister of Communication. Thirdly, he closed the doors of BPA to his rivals in the opposition, saying 'this is what happened to him when he was in the opposition', according to a former cabinet minister who backed the Tito regime (R. Bwataromwa, personal communication, August 2002).

\section{Real-life situations}

In 1999, Ieremia Tabai applied for a licence to start a radio station, Newair FM89, but the government did not grant him one for almost four years. I know that personally because I covered this story in spite of some restrictions. Later, Tabai set up his newspaper using it to tell the public that his station was banned because he knew that the BPA could not broadcast any story about his struggle to get a licence:

I never liked the last government [of Tebuboro]. One of the reasons is because they monopolised the media in such a way that they controlled it. I thought it was very bad in a small country like Kiribati to have one media outlet only. When the government knew that they were losing the battle, they gave me the licence (cited by Ausaid, 2005, p. 177). 
Of course, we did provide coverage on Tabai's struggle but the board always checked and 'edited' the story before it was broadcast. Teburoro knew that what he did to BPA was not enough for him as other players have now entered the media field - the Kiribati Newstar. To counter criticism, Tito amended the Newspaper Registration Act in 2002 to target the new newspaper that was critical of his government - the Newstar. Despite Tito's claim that he did not intend to shut this paper, the motives and amendments were clear: if the newspaper ran a story without obtaining the comment of the person in question, it would be fined or deregistered.

In 2001, the Kiribati government planned to start a new air service between small island member states of the Pacific Islands Forum, a move supported by the Forum Secretariat. At the time, Kiribati authorities were not aware that the Tuvalu government and Air Fiji had signed a contract giving the Fiji airline exclusive rights over routes between Funafuti and Nadi. On 31 July 2002, I reported on the failure of the French-based aircraft ATR 72 leased by the government for the air service - and I paid the price as a journalist. The Kiribati government was charged by the Forum for leasing this aircraft that had not got a certificate of airworthiness from Fiji to operate. The Kiribati government was embarrassed when I interviewed Tuvalu's Foreign Affairs Secretary, Tine Leuelu, asking him to comment on 'whether they know why ATR 72 had not started its flights' (Radio Kiribati, 31 July 2002).

On 2 August 2002, the BPA executives cautioned me, saying it was an 'unbalanced and untrue' story. The aircraft had been standing at the airport but the authority did not run any story about it because the management was scared. The story was in the public interest because the aircraft had been leased for hundreds of thousands of dollars in taxpayers' money at a rate of A $\$ 400,000$ a month. In addition, a commercial service could not be started because the aircraft did not have any certificate of airworthiness. When the Opposition came to power in 2003, it terminated the contract with the ATR company and returned the aircraft to France. Minister of Communications Natan Teewe revealed later the aircraft could not fly to Christmas Island, it was not a jet aircraft, and the government had spent more than A \$20 million between 2001 to 2004 (Teewe, 2007).

The government of Anote Tong promised greater freedom to the state media, something that previous leaders often declared when they campaigned prior to the general elections. When actually elected to office, the leaders did 
the opposite. The Tong administration was quite outspoken and vocal over the Tito government's stance over media freedom. At present, President Tong does not show much responsibility towards his call for media freedom: 'We are tired of this investigative reporting, something that we did not see when we were in the opposition.' This was his message to the editors of BPA who were on suspension for disobeying the minister's order but had sought the President's help to intervene (President Tong, personal communication, 18 October 2005). His minister, Natan Teewe and the Attorney-General, attacked us, accusing us of being a 'public nuisance'. They said reporters of BPA were only public informers and could not investigate stories like agencies such as the FBI or CIA. 'There was no section within [the] BPA Act that guarantees the rights of journalists to carry out investigative reporting,' added Tiitabu Taabane (Pacnews, 1 August 2005). They also warned the general manager to be cautious about stories broadcast and published by the authority. However, we kept on reporting as usual, particularly as the manager backed us up right from the beginning. 'BPA will continue to inform, educate and entertain the public as stipulated under the authority's statute,' he said in a statement (ibid.).

These were some of the stories we broadcast in July and August 2005, prompting the senior executives to verbally admonish us.

- Wife of the President implicated in the Red Cross fund abuse-22 July 2005

- Catholic Bishop calling on President to step down because of prostitution - 6 July 2005

- Speaker took his driver to Taiwan at the public expense-18 July 2005

- Financial irregularities: 90,000 overpayment to a church car dealer-August 2005

- $\quad \$ 1.7 \mathrm{~m}$ imprest outstanding-August 2005

The BPA board intervened and ordered an investigation into stories that it described as 'offensive' to the public. The board never provided us with official documents on who 'complained' and what was the 'nature' of the complaint. So we believed that the investigation was a form of political threat to our duty as 'journalists'. And we did some reporting on this investigation in an attempt to mobilise public opinion and support to defend our credibility. We interviewed church leaders, several academics, politicians and members of the public to get their views on this investigation. The board was quite 
disappointed and embarrassed and so was the government when the response from the public towards this probe was 'negative'. In other words, the church leaders, community and NGOs told us that they were not offended.

Then who was offended? To bring an end to this stand-off, the minister stepped in by issuing his notice to restrain the authorities - reporters-from publishing and broadcasting the boardís investigation. He said the dispute between the board and the reporters was just a matter between the master and his servant. Perhaps the minister had missed out an important point - the root of the dispute is press freedom - a freedom promised during their campaign (Korauaba, 2003, p. 11).

I reported on the minister's order in September 2005 and was suspended for 20 working days without pay. I resumed work after the suspension and continued my investigation into the $\$ 1.7$ million in outstanding imprest. As a result, my source, a reliable person working at the Finance Department, said the Auditor-General owed the government some thousands of dollars and he was still being paid with imprest for his overseas trips. Under the conditions of service, an employee must retire or return the fund before he could be issued another fund. The Auditor-General wrote a letter to the manager of theKiribati Provident Fund, giving him the authority to deduct his debts from his contributions on retirement so he could receive his entitlements. When the board became aware of this, it instructed the Acting General Manager, Tibwere Boobo (2005) to write a letter to me. The letter was an attempt to force me to disclose the name of my source or documents. It gave me 24 hours to comply with the letter.

When I refused to follow the board's directive on 6 December 2005, management fired me the following day. I appealed against the management decision to the board but was not successful. A board member, and key government supporter, Rooniti Teiwaki, said during the appeal that they were 'tired of my style of reporting'. Later, the board informed me that it had rejected my appeal, stating also that I had not been prepared to show remorse for disobeying the directive.

International media freedom organisations took up my case and Reporters Sans Frontières issued a statement in Paris (2006) under the headline 'Public radio journalist fired for refusing to disclose sources for report on corruption'. The statement said: 
It is highly regrettable that the management of a public news media [organisation] should fire a young journalist like this, especially one highly motivated to inform his country's inhabitants. This case shows the limits of press freedom in Kiribati. We call on the Broadcasting and Publications Authority to reinstate Korauaba at once (RSF/IFEX, 2006).

An independent newspaper, Kiribati Newstar, remained silent, never publishing any story about my dismissal. This has given government greater control and dominance in the press. I do not know what the publisher, Ieremia Tabai, would say about that - he was the person who was critical about the last government for its restrictions on the media. The government is believed to insert its weekly newsletter with the Newstar for a weekly subsidy of about $\$ 100$ from taxpayers' money.

I know that they have the power to gag a reporter who is trying to tell the truth to the public. But the saddest thing is that the reporters of the authority are too scared and cannot report on anything that may embarrass their political masters because it could cost them their job. I am happy because I have defended the credibility of my profession, something I believe to be worthwhile. The BPA has fired me and I have been threatened and sanctioned on a number of occasions. This prompted me to move to New Zealand with my family and publish a new Kiribati community newspaper, Tematairiki. ${ }^{1}$

I was not the only well-trained and qualified journalist in Kiribati. But what I did to bring about the change has given us an interesting case study: I represent change and the government represents the past. The law, which gave government absolute power over BPA, is an anachronism and does not meet the current needs of the public and the press in Kiribati. It was enacted 50 years ago and is now irrelevant.

\section{Recommendations}

The BPA will not be free if the government of the day does not act now, or incoming leaders will do the same - use it for their political will. They need to consider the following if they are willing to make an immediate change:

- Revision of the BPA Ordinance 1979

- Provision of a Freedom of Information Act

- Introduction of a Bill of Rights for the Kiribati constitution

- Removal of the minister's power over the BPA unless the issue in question concerns public morality or safety 
- Granting freedom to the editorial team of BPA overseeing the radio and newspaper

- Encouraging support from regional media organisations to help the media in Kiribati establish a media council

\section{Conclusion}

I have outlined my experience with the press in Kiribati. It is clear at the outset that the press in Kiribati is largely dominated by the governmentowned Broadcasting and Publications Authority. For the past half century, governments dominated the authority and used it to promote their political agendas. This, I believe, happened during the colonial administrationwhen the British used BPA to convey their message, and there was no press freedom at that time. However, our political leaders have acted as if they are the new colonial masters of the BPA. The BPA cannot carry out its duties as a watchdog in Kiribati because the government still thinks that press freedom belongs only to Western countries. They used the outdated law as an excuse to justify their call to censor BPA.

The government needs to take a closer look at broadcasters like Radio Fiji and the Solomon Islands Broadcasting Corporation to examine their independent broadcasting protocols. Radio Fiji might broadcast such stories as the agricultural scam, which in 2006 led to the jailing of former Permanent Secretary for Agriculture Peniasi Kunatuba ([Kunatuba] guilty, assessors rule, 2006). But it is very hard to hear such stories in Kiribati because of government restrictions on the media. The government must allow the BPA to do any kind of story without interference. Its job is to check on 'the temperature of the government of the day'. This is a core duty of BPA which is being suppressed by governments and no President has ever attempted to grant media freedom to this station.

\section{Note}

1. Tematairiki News www.tematairiki.zoomshare.com

\section{References}

Ausaid (2005). Informing citizens: opportunities for media and communications in the Pacific. Canberra: Pacific Media and Communications Facility.

Australian Press Council (2000) Country Report-Kiribati (Retrieved 1 December 2006): www.presscouncil.org.au 


\section{JOURNALISM DOWNUNDER}

Boobo, T. (2005). BPA Acting General Manager's letter to the author, December 5. [Kunatuba] guilty, assessors rule. (2006, November 15), The Fiji Times, p. 1.

Korauaba. T. (2003, September). Kiribati government promises greater media freedom, Wansolwara, p. 11

RSF/IFEX (2006, January 13). Public radio journalist fired for refusing to disclose sources for report on corruption. (Retrieved from IFEX International Freedom of Expression eXchange website, 20 November 2006): www.ifex.org/en/content/view/full/71539

Teburoro Tito (2001). President of Kiribati (Retrieved 1 December 2006): http://ijc.md/en/activities/pfw/quotes.html www.worldaudit.org/presstext.htm Kiribati: F 5-9-14=28

Teabo. T. (2005, October 4). Editors are on suspension, Radio Kiribati. Teabo, T. (2005, October 6). Investigation mounting, Radio Kiribati. Teabo. T. (2005, October 7). No media freedom in Kiribati, Radio Kiribati. Teewe, N. (2007). Minister of Communications letter to Tematairiki, March 21. Transparency International report 2004. (Retrieved 1 December 2006) : http://www.transparency.org.au/documents/kiribati.pdf

Taberannang Korauaba is publisher of the $i$-Kiribati newsletter Tematairiki. Formerly a senior journalist and editor with the Broadcasting and Publications Authority (BPA) in Kiribati, he now lives in Warkworth, New Zealand. An earlier version of this commentary was presented as a paper at the Second Joint Journalism Education (JEA)/Journalism Education Association of New Zealand (JEANZ) conference, Auckland, December 4-7. tkorauaba@xtra.co.nz 
Copyright of Pacific Journalism Review is the property of Auckland University of Technology and its content may not be copied or emailed to multiple sites or posted to a listserv without the copyright holder's express written permission. However, users may print, download, or email articles for individual use. http://www.aut.ac.nz/depts/commstud/journ/pjrsubs.shtml 